\title{
DERMATOGLIFI PADA AUTISME DAN SINDROM DOWN DI PALEMBANG
}

\author{
Altiara Risky Suciandari ${ }^{1}$, Trisnawati Mundijo², Mitayani Purwoko ${ }^{3}$ \\ 1,Mahasiswa Fakultas Kedokteran Universitas MuhammadiyahPalembang \\ 2,3Departemen Biologi Kedokteran Fakultas Kedokteran Universitas MuhammadiyahPalembang
}

\begin{abstract}
ABSTRAK
Dermatoglifi adalah ilmu yang mempelajari pola sidik jari, jumlah sulur dan jumlah triradius yang perkembangannya diatur oleh genetik. Kelainan kromosom dapat mempengaruhi fenotip dermatoglifi diantaranya adalah Autisme dan Sindrom Down. Penelitian ini bertujuan untuk mengetahui pola sidik jari pada penderita Autisme dan Sindrom Down. Penelitian ini bersifat deskriptif dengan sampel penelitian berjumlah 76 penderita yaitu 46 penderita Autisme dan 30 penderita Sindrom Down yang diambil secara total sampling di YPAC, YBAM dan Klinik Autis Anakku Palembang. Dari hasil penelitian pola loop merupakan pola sidik jari terbanyak pada Autisme (57,2\%) dan pada Sindrom Down (80,7\%). Sedangkan pola arch merupakan pola sidik jari yang paling sedikit yaitu Autisme (3,7\%) dan Sindrom Down (5,3\%). Hasil penelitian disimpulkan penderita Autisme dan Sindrom Down di Palembang sebagian besar memiliki pola sidik jari loop.
\end{abstract}

Kata Kunci: Autisme, Sindrom Down, pola sidik jari, sudut ATD.

\section{ABSTRACT}

Dermatoglyphics is a study that concern of fingerprint pattern, the number of tendrils and the number of triradius whose development is regulated by genetic. Chromosome abnormalities can affect the dermatoglyphic phenotype such as in Autism and Down syndrome. This study aimed to explore the fingerprint pattern in Autism and Down syndrome patient in Palembang. This research was designed as a descriptive study with total sampling. The sample of this research was 76 patients consisted of 46 Autism patients and 30 Down syndrome patients from special schools YPAC, YBAM and Autis Anakku Clinic in Palembang. The result of this research was loop pattern is the highest fingerprint pattern on Autism (57.2\%) and on Down Syndrome (80.7\%). While the arch pattern is the lowest fingerprint pattern of Autism (3.7\%) and Down Syndrome (5.3\%). The conclusion is, people with Autism and Down syndrome in Palembang mostly have a loop fingerprint pattern.

Key Words: Autism, Down syndrome, fingerprint pattern, ATD angle.

\section{PENDAHULUAN}

Anomali kongenital adalah istilah yang digunakan untuk menjelaskan gangguan struktural, perilaku, fungsional dan atau metabolik yang ada sejak lahir. Anomali kongenital adalah lima dari penyebab utama hilangnya tahun kehidupan yang potensial sebelum usia 65 tahun dan sebagai penyumbang utama disabilitas. Anomali kongenital disebabkan oleh banyak faktor, yaitu 15\% karena faktor genetik akibat kelainan kromosom dan gen mutan, $10 \%$ karena faktor lingkungan, 20-25\% merupakan kombinasi antara faktor genetik dan lingkungan (pewarisan multifaktorial), dan 0,5-1\% karena kehamilan kembar, serta 40-60\% tidak diketahui penyebabnya. ${ }^{1}$ Anomali kongenital yang disebabkan oleh faktor genetik karena abnormalitas kromosom di antaranya adalah Autisme dan Sindrom Down., ${ }^{2,3}$

Autisme adalah gangguan perkembangan saraf yang kompleks yang ditandai oleh gangguan signifikan pada fungsi sosial dan perilaku sosial. ${ }^{4}$ Diketahui bahwa dua regio pada kromosom 2 dan 7 mengandung gen yang terlibat di dalam Autisme, selain itu juga ditemukan pada kromosom 16 dan 17.5 Selain Autisme, anomali kongenital yang disebabkan oleh faktor genetik lainnya adalah 
Sindrom Down yang merupakan suatu kondisi keterbelakangan fisik dan mental anak yang diakibatkan adanya abnormalitas perkembangan kromosom akibat ekstra kromosom 21 sebagai hasil dari gagalnya pemisahan saat pembentukan gamet.6,7

Studi tentang sulur epidermal memiliki berbagai kegunaan. Hal ini berguna dalam identifikasi personal sebagai alat bantu diagnostik untuk berbagai penyakit genetik seperti sindrom Down, Autisme, Skizofrenia dan kasus medikolegal. 8

Dalam suatu penelitian penderita Autisme memiliki jumlah loop yang lebih banyak dibandingkan individu yang normal, sedangkan dalam penelitian lainnya didapatkan penderita Autisme memiliki peningkatan pola arch dan radial loop pada tangan kanan serta peningkatan arch dan ulnar loop pada tangan kiri.4,9 Penderita Sindrom Down di Banjarmasin dan Martapura di Kalimantan Selatan diketahui terdapat peningkatan jumlah loop sebesar 60\%. ${ }^{10}$ Pada penelitian lainnya didapatkan peningkatan jumlah arch dan ulnar loop sebesar 63,4\% pada tangan kiri serta peningkatan whorl dan radial loop pada tangan kanan. ${ }^{11}$

Belum banyak penelitian mengenai dermatoglifi, sehingga dilakukan penelitian untuk mengeksplorasi apakah terdapat pola sidik jari yang khas pola sidik jari penderita Autisme dan Sindrom Down di Palembang.

\section{BAHAN DAN METODE}

Penelitian ini merupakan penelitian deskriptif dengan populasi dan sampel semua penderita Autisme yang bersekolah di Yayasan Pembinaan Anak Cacat, Yayasan Bina Autis Mandiri dan Klinik Autis Anakku Palembang dan semua penderita
Sindrom Down yang bersekolah di Yayasan Pembinaan Anak Cacat Palembang.

Kriteria inklusi penelitian adalah laki-laki dan perempuan yang sudah didiagnosis menderita Autisme dan Sindrom Down oleh dokter sesuai dengan catatan rekam medik, sedangkan kriteria eksklusi adalah orang tua/wali tidak mengizinkan anaknya untuk ikut serta dalam penelitian.

Data penelitian merupakan data primer dan sekunder yang dikumpulkan saat melakukan penelitian terhadap semua penderita Autisme dan Sindrom Down di Yayasan Pembinaan Anak Cacat, Yayasan Bina Autis Mandiri dan Klinik Autis Anakku Palembang pada Bulan Desember 2017. Data didapatkan dengan melakukan pengolesan lipstik pada setiap ujung jari yang selanjutnya ditempelkan pada lembar observasi.

Data diolah dengan menganalisis semua pola yang terbentuk dari semua jari tangan dan di analisis univariat untuk mengidentifikasi distribusi pola sidik jari.

\section{HASIL DAN PEMBAHASAN}

Dari hasil penelitian di Yayasan Bina Autis Mandiri Palembang didapatkan sebanyak 34 penderita Autisme, di Yayasan Pembinaan Anak Cacat Palembang sebanyak 47 penderita dengan 11 penderita Autisme dan 30 penderita Sindrom Down dan di Klinik Autis Anakku Palembang terdapat satu penderita Autisme. Sehingga didapatkan total responden penderita Autisme sebanyak 46 responden dan penderita Sindrom Down sebanyak 30 responden.

Hasil penelitian didapatkan pola yang paling banyak adalah pola loop sebanyak 263 jari tangan $(57,2 \%)$ pada penderita Autisme dan 242 jari tangan (80,7\%) pada penderita Sindrom Down, sedangkan 
pola yang paling sedikit adalah pola arch sebanyak 17 jari tangan (3,7\%) pada penderita Autisme dan 17 jari tangan (5,3\%) pada penderita Sindrom Down.

Peningkatan pola loop dan sedikitnya pola arch pada Autisme dan Sindrom Down kemungkinan terjadi karena pada sidik jari manusia pola dasarnya adalah pola loop dan variasi gen menyebabkan deviasi (penyimpangan) dari pola sidik jari dasar ini menjadi pola-pola lain. Sesuai dengan penelitian yang dilakukan oleh Bhat bahwa pola loop merupakan pola terbanyak pada pola sidik jari manusia yang mencapai $60-70 \%$, pola whorl sekitar 25-35\% dan yang paling sedikit adalah pola archhanya 5\%.12 Hasil yang sama ditemukan dalam penelitian De Bruin et.al bahwa anak Autisme memiliki pola loop yang lebih banyak dibandingkan dengan pola whorl dan arch daripada anak normal. ${ }^{13}$ Hasil serupa didapatkan pula dalam penelitian yang dilakukan oleh Stosjelvic dan Adamovic yaitu, penderita Autisme memiliki jumlah loop yang lebih banyak $(9,17 \%)$ dibandingkan yang normal $(4,34 \%) .{ }^{14}$ Sedangkan penelitian pola sidik jari pada penderita Sindrom Down di Purwokerto yang dilakukan oleh Irawan et.al didapatkan juga bahwa pola terbanyak adalah pola loop $(63,4 \%)$ dan hasil yang sama pada penelitian yang dilakukan di Banjarmasin didapatkan pola terbanyak adalah ulnar loop $(75,83 \%)$ dan yang paling sedikit adalah pola arch $(6,24 \%) .{ }^{11}$ Hal ini terjadi karena menurut Penrose penderita Sindrom Down memiliki kecendrungan kuat untuk memiliki tipe pola loop disetiap jarinya. ${ }^{10}$

Selain dikarenakan pola dasar sidik jari manusia adalah pola loop, peningkatan pola loop pada Autisme dan Sindrom Down kemungkinan juga disebabkan karena terdapat persamaan secara patogenesis sehingga pada kedua penyakit ini terjadi peningkatan pola yang sama. Secara patogensis, Autisme dan Sindrom Down merupakan gangguan perkembangan yang terjadi karena aberasi kromosom, disregulasi dan mutasi gen prekusor $\beta$ amiloid yang mengganggu perkembangan otak selama gestasi. Struktur tubuh seperti otak, kelenjar payudara, bibir dan alveoli berkembang pada periode yang sama dengan sulur jari. Sehingga perkembangan abnormal organ tersebut pada saat gestasi tercermin dalam pola dermatoglifi. ${ }^{15,16}$

Hal yang berbeda ditemukan dalam penelitian yang dilakukan oleh Gabriel di Nigeria, bahwa pada anak Autisme pola arch merupakan pola terbanyak $(49,5 \%)$ diikuti pola ulnar loop $(28,5 \%)$, whorl $(18,5 \%)$ dan radial loop (3,5\%). ${ }^{9}$ Perbedaan ini kemungkinan terjadi karena adanya faktor perbedaan etnik yang dapat mempengaruhi pola

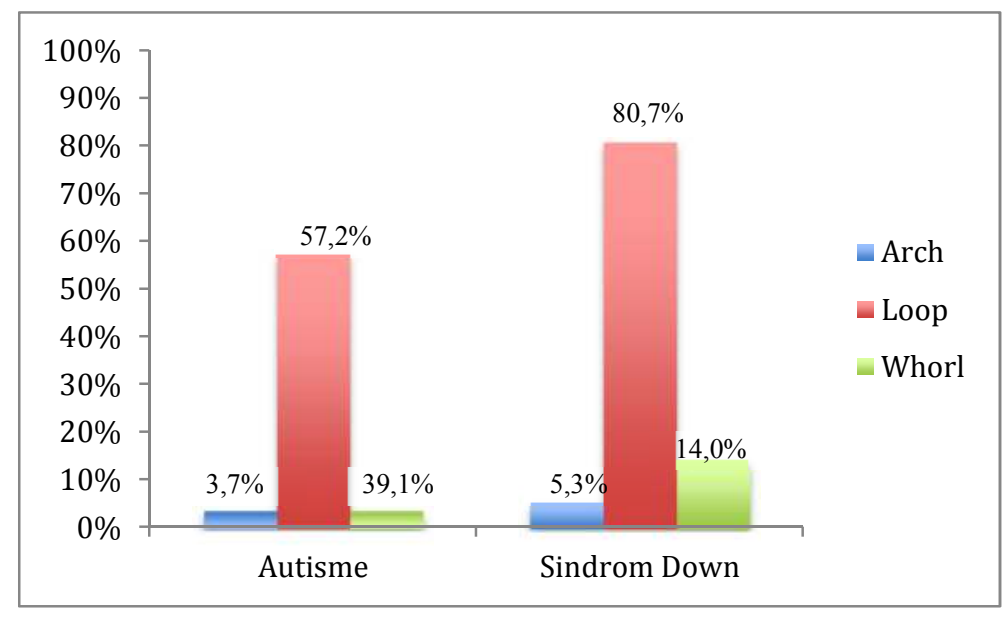

Vol. 1 No.5 Agustus 2018

http://jurnal.unimus.ac.id 
Gambar 1. Hasil Perbandingan Pola Sidik Jari Penderita Autisme dan Sindrom Down

sidik jari dalam populasi. Dalam ribuan studi antropologi yang telah dilakukan pada populasi yang berbeda untuk mengidentifikasi pembentukan pola sidik jari, didapatkan bahwa variasi pola sidik jari pada suatu etnis dapat dipengaruhi oleh beberapa gen dan gen tersebut saling berinteraksi yang akhirnya akan menghasilkan pola yang dominan pada suatu populasi yang berbeda dengan populasi lainnya. ${ }^{17}$ Menurut Cavalli-Sforza terdapat hubungan apabila fragmen populasi tunggal menjadi sangat terisolasi satu sama lain, mereka akan berdiferensiasi walaupun tidak adanya mutasi dan seleksi alam. Proses perubahan tersebut menyebabkan frekuensi gen masing-masing berubah yang disebut drift sehingga dapat menghasilkan perbedaan dermatoglifi pada setiap etnik. ${ }^{18}$

Penelitian pola sidik jari pada Sindrom Down yang dilakukan oleh Ainur, Hastuti dan Nugraha, menunjukan hasil yang berbeda dengan penelitian ini yaitu pola sidik jari yang paling banyak pada penderita Sindrom Down adalah whorl (55\%) diikuti ulnar loop (41\%), radial loop (3\%) dan arch $(1 \%) .{ }^{19} \mathrm{Hal}$ ini kemungkinan terjadi karena adanya pengaruh variasi pola pada masa gestasi yang dapat menjadi penyebab timbulnya keberagaman frekuensi pola pada sidik jari. Variasi pola ini ditentukan oleh padatan badan volar yang dipengaruhi oleh interaksi genetik dengan lingkungan intrauterin. Badan volar janin merupakan penentu pola yang akan terbentuk pada jari. Pertumbuhan dan regresi bantalan volar menghasilkan tekanan fisik yang bervariasi diseluruh permukaan volar yang akan mempengaruhi keseimbangan pola sidik jari. Ketidakseimbangan tersebut dapat menjadi salah satu faktor ketidakstabilan lapisal sel basal epidermis sehingga dapat menghambat pembentukan alur dan lipatan untuk pertumbuhan diferensial lapisan basal dan regresi bantalan volar yang akan mempengaruhi pembentukan pola sidik jari pada individu. 17,20

Faktor genetik dapat mempengaruhi pola sidik jari pada individu. Hasil penelitian dari 90\% data, dapat disimpulkan bahwa pola sidik jari dipengaruhi juga oleh faktor genetik, sehingga terdapat kecenderungan pola yang sama pada saudara kandung dan saudara kembar. Temuan ini telah menghasilkan pengembangan berbagai model untuk menjelaskan hubungan genetika yang mengendalikan efek gen pleiotropik dan mengasumsikan bahwa faktor genetik dapat menentukan variasi pola sidik jari. Hasil studi menemukan bahwa adanya keterkaitan pembentukan pola sidik jari dengan kromosom 5q14.1. Pada kromosom 5 terdapat sejumlah gen zinc-finger (ZFYVE16, ZCCHC9, dan ZBED3), puncak kromosom 19 (85 cM) yang berhubungan dengan gen zinc-finger dan pada puncak kromosom 15 (55 cM) berada dalam 5 cM gen FBN1 yang berhubungan dalam mempertahankan serat elastis dan sel epitel pengikat ke matriks interstisial. Sehingga pengaruh dari beberapa gen ini dapat mengakibatkan variasi polimorfik perkembangan digit, bantalan volar dan sulur jari. ${ }^{2}$

\section{KESIMPULAN DAN SARAN}

Pola sidik jari pada penderita Autisme dan Sindrom Down di Kota Palembang didapatkan bahwa pola sidik jari terbanyak adalah pola loop diikuti pola whorl dan arch.

\section{DAFTAR PUSTAKA}

1. Langman, J. 2014. Embriologi Kedokteran. Jakarta : EGC. Hal. 97. 
2. Pinto et al. 2014. Convergence of Genes and Cellular Pathways Dysregulated in Autism Spectrum Disorders. The American Joumal of Human Genetics 94, 1-18. http://dx.doi.org/10.1016/j.ajhg.2014.03.018. Diakses 13 Juli 2017

3. Canick et al. 2012. DNA Sequencing of Maternal Plasma to Identify Down Syndrome and other Trisomies in Multiple Gestations. Prenatal Diagnosis 32, 1-5. Genetics in medicine. http://doi.org/10.1002/pd.3892. Diakses 13 Juli 2017

4. Kazemi et.al. 2017. Comparative Dermatoglyphic Study between Autistic Patients and Normal People in Iran. Iran Journal Med Sci July Vol 42 No 4. https://www.ncbi.nlm.nih.gov. Diakses 11 Juli 2017

5. Kaplan dan Sadock. 2011. Buku Ajar Ilmu Psikiatri Klinis. Ed-2. EGC. Jakarta, Indonesia. Hal. 291.

6. Judarwanto, W. 2012. Down Syndrome: Deteksi Dini, Pencegahan dan Penatalaksanaannya. Clinic for Cbildren Information Education Network. http://goo.gl/fW AKS. Diakses 17 Januari 2018

7. Meadow dan Newell. 2005. Pediatrika: Abnormalitas Klinik Karena Kromosom (Edisi ketujuh). Jakarta: Penerbit Erlangga. Hal. 53.

8. Loveday O.E dan Sunday O.R. 2015. An Improvise Easy Digital Method for Palmar and Plantar Dermatoglyphics. Bioscience and Bioengineering Vol. 1, No. 3, 85-89. http:// files.aiscience.org. Diakses 15 Juli 2017

9. Gabriel, S.O. 2013. Dermatoglyphic Patterns of Autistic Children in Nigeria. Journal of Biology, Agriculture and Healthcare. ISSN 2224-3208 (Paper) ISSN 2225-093X (Online) Vol.3, No.7. https://www.researchgate.net. Diakses 11 Juli 2017

10. Rosida, L. dan Panghiyangani, R. 2006. Gambaran Dermatoglifi Pada Penderita Sindrom Down di Banjarmasin dan Martapura Kalimantan Selatan. Jurnal Anatomi Indonesia. Volume 01: 71-78. https://journal.ugm.ac.id. Diakses 16 Mei 2017
11. Irawan R.B, Rujito L, Ferine $M$ dan Hidayat Z.S. 2010. Perbedaan Pola Sidik Jari AnakAnak Sindrom Down dan Anak-Anak Normal di Purwokerto. Sains Medika Vol.2, No. 2, http://sainsmedika.fkunissula.ac.id. Diakses 16 Mei 2017

12. Bhat, G.M., Mukhdoomi, M.A., Shah, B.A.,\& Ittoo, M.S. 2014. Dermatoglyphics: in health and disease (review). International Journal of Research in Medical Sciences, 2(1), 31-37. Available at http://doi.org/10.5455/23206012.ijrms20140207. Diakses 15 Januari 2018

13. De Bruin E.I, Graham J.H, Louwerse A dan Huizink A.C. 2012. Mild Dermatoglyphic Deviations in Adolescents with Autism Spectrum Disorders and Average Intellectual Abilities as Compared to Typically Developing Boys. Autism Research and Treatment. http://dx.doi.org/10.1155/2014/968134. Diakses 11 Juli 2017

14. Stosjelvic dan Adamovic. 2013. Dermatoglyphic Characteristics of DigitoPalmar Complex in Autistic Boys in Serbia. https://www.ncbi.nlm.nih.gov. Diakses 17 Januari 2018

15. Mohd, B. 2014. Dermatoglyphics: in Health and Disease - a Review. International Journal of Research in Medical Sciences. pISSN 2320-6071 | eISSN 2320

6012.http://dx.doi.org/10.5455/23206012.ijrms20140207. Diakses 16 Agustus 2017

16. Liao et.al. 2013. Chromosomal Abnormalities in Patients With Autism Spectrum Disorders From Taiwan. American Journal of American Genetics.

https://www.ncbi.nlm.nih.gov/pubmed/2413 2905. Diakses 14 Januari 2018

17. Holder, Jr. 2002. U.S. Department of Justice Office of Justice Programs. Hal. 20.

18. Temaj et.al. 2011. Comparative Analysis of Qualitative Dermatoglyphic Traits of Albanian and Turkish Populations Living in the Area of Dukagiin Valley in Kosovo. Institute for Anthropological Research, Gajeva 32, 10000 Zagreb, Croatia. https://www.ncbi.nlm.nih.gov. Diakses 16 Agustus 2017

19. Ainur A, Hastuti J dan Nugraha Z.S. 2009. Pola Sidik Jari Anak-Anak Sindrom Down di 
SLB Bakhti Kencana dan Anak-Anak Normal di SD Budi Mulia Dua Yogyakarta. Jurnal Kedokteran dan Kesehatan Indonesia. http://www.jurnal.uii.ac.id. Diakses 16 Mei 2017
20. Elsevier. 2015. Common Genetic Variants Influence Whorls in Fingerprint Patterns. Journal of Investigative Dermatology (2016) 136, 859e862; doi:10.1016/j.jid.2015.10.062. Diakses 17 Januari 2018

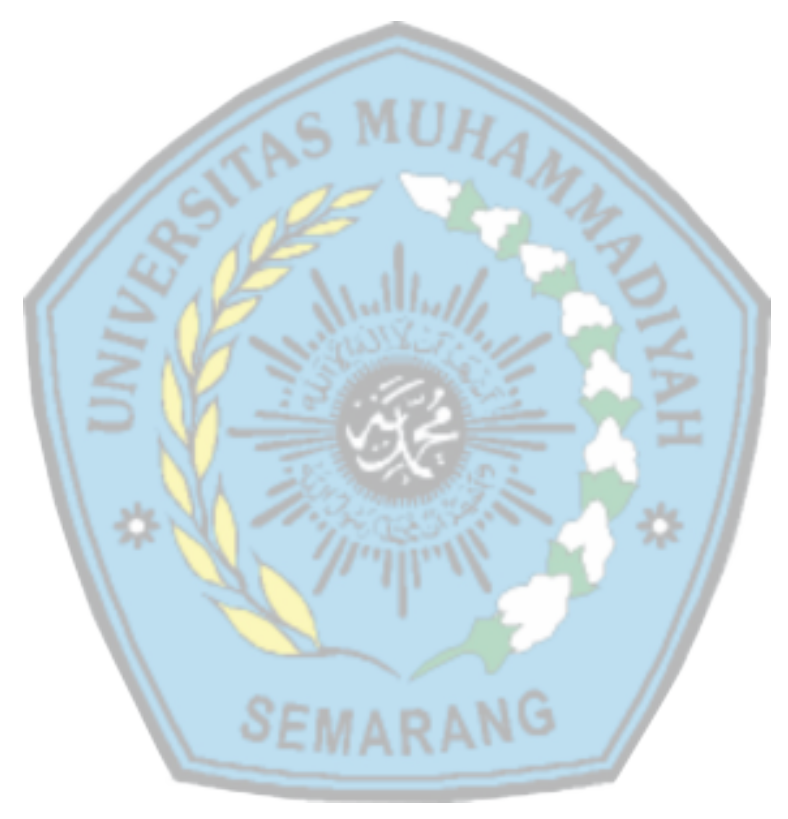

